\title{
Control of phytoplankton production and biomass in a river-dominated estuary: Apalachicola Bay, Florida, USA
}

\author{
Behzad Mortazavi ${ }^{1, *}$, Richard L. Iverson ${ }^{1}$, William M. Landing ${ }^{1}$, \\ F. Graham Lewis ${ }^{2}$, Wenrui Huang ${ }^{3}$
}

\author{
'Department of Oceanography, Florida State University, Tallahassee, Florida 32306-4320, USA \\ ${ }^{2}$ Northwest Florida Water Management District, Route 1, Box 3100, Havana, Florida 32333-9700, USA \\ ${ }^{3}$ FAMU-FSU College of Engineering, 2525 Pottsdamer St., Tallahassee, Florida 32310-6046, USA
}

\begin{abstract}
Physical, chemical, and biological processes interact in complex patterns through time to control estuarine phytoplankton productivity and biomass. Hydrodynamic model results, together with biological, nutrient, and physical data acquired from Apalachicola Bay from May 1993 through May 1996, were used to elucidate factors that control phytoplankton productivity and chlorophyll (chl a). The estuary receives freshwater, which originates in the Apalachicola, Chattahoochee, and Flint River watersheds, with maximum river flow occurring in late winter and early spring. Maximum chl a

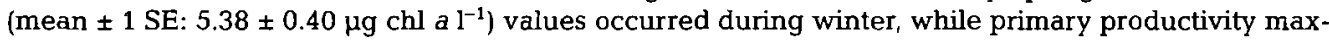
ima occurred in late spring and summer months when temperature and photosynthetically active radiation (PAR) reached their annual maxima. Approximately $75 \%$ of annual primary production (255 \pm $78 \mathrm{~g} \mathrm{C} \mathrm{m}^{-2} \mathrm{yr}^{-1}$ ) occurred from May through November of each year. During this period, however, river dissolved inorganic nitrogen and soluble reactive phosphorus input accounted for $40 \%$ of the annual inputs $\left(30.9 \pm 5.1 \mathrm{~g} \mathrm{~N} \mathrm{~m}^{-2} \mathrm{yr}^{-1}\right.$ and $0.60 \pm 0.15 \mathrm{~g} \mathrm{P} \mathrm{m}^{-2} \mathrm{yr}^{-1}$, respectively). Approximately $25 \%$ of annual primary production occurred from December to April, concurrent with low PAR values and low water temperature. Low chl a concentrations in summer months were concurrent with high phytoplankton productivity, high zooplankton abundance, low river flow, and low nutrient input to the estuary. In 2 of 3 years, export from Apalachicola Bay provided a significant control for phytoplankton biomass magnitude during winter. However, on an annual basis grazing accounted for $80 \%$ of the chl $a$ loss from the estuary.
\end{abstract}

KEY WORDS: Estuary $\cdot$ Primary production $\cdot$ Nitrate $\cdot$ Phosphate $\cdot$ Chlorophyll $\cdot$ Grazing $\cdot$ Residence time

\section{INTRODUCTION}

Estuaries are highly productive and dynamic ecosystems situated at the interface between freshwater and saltwater. They provide an important nursery ground for many fish and invertebrate species and support over $50 \%$ of the United States' annual fishery harvest (Houde \& Rutherford 1993). Phytoplankton provide a link between inorganic compounds and organic matter available to higher trophic levels. It is, therefore,

\footnotetext{
•E-mail: mortazavi@ocean.fsu.edu
}

important to understand the factors that regulate phytoplankton production and biomass in estuaries.

Phytoplankton production and biomass in estuaries are affected by different physical and chemical factors at different times of the year. The greater fraction of annual primary production in temperate estuaries is realized during summer months when photosynthetically active radiation (PAR) values are greatest. Nutrient concentrations, and more specifically those of nitrogen and phosphorus, limit phytoplankton productivity in marine environments (Ryther \& Dunstan 1971, Hecky \& Kilham 1988). Either phosphorus or nitrogen can limit phytoplankton productivity and biomass at 
different seasons or different locations during the same season in an estuary (Myers \& Iverson 1981, Malone et al. 1996, Fulmer 1997). Temporal alternation between light-limitation and nutrient-limitation of phytoplankton productivity has been reported by Pennock \& Sharp (1994). Monbet's (1992) analysis of 40 estuaries revealed that chlorophyll a ( $\mathrm{chl}$ a) concentrations are affected by an interaction between nitrogen input and tidal mixing. Water residence time in estuaries influences nitrogen retention (Nixon et al. 1996) and affects primary production and biomass. During periods when water residence time is shorter than phytoplankton doubling time, advective loss becomes the dominant factor controlling phytoplankton biomass (Cloern et al. 1985). Finally, grazing can be a dominant factor in the control of phytoplankton biomass in estuaries (Stockner et al. 1979, Malone 1992, Dagg 1995a, Lonsdale et al. 1996a, Lehrter et al. 1999).

Apalachicola Bay, a bar-built estuary with an area of $260 \mathrm{~km}^{2}$ and a mean depth of $2.2 \mathrm{~m}$, is situated in the northern Gulf of Mexico (Fig. 1). The estuary has a tidal range of $0.5 \mathrm{~m}$ and is connected to the gulf by 3 natural passes and an artificial inlet. The Apalachicola River, with the largest flow rate of Florida rivers, is the estuary's freshwater source. The Apalachicola River drainage basin, with an area of $44000 \mathrm{~km}^{2}$ (Fu \& Winchester 1994), is located in western Georgia, southeastern Alabama, and northern Florida, and is considered one of the least polluted in the US (Livingston 1984). In Florida, the river is bordered by an extensive, forested flood plain. Some aspects of the phytoplankton ecology of Apalachicola Bay, Florida, have been reported (Estabrook 1973, Myers \& Iverson 1977).

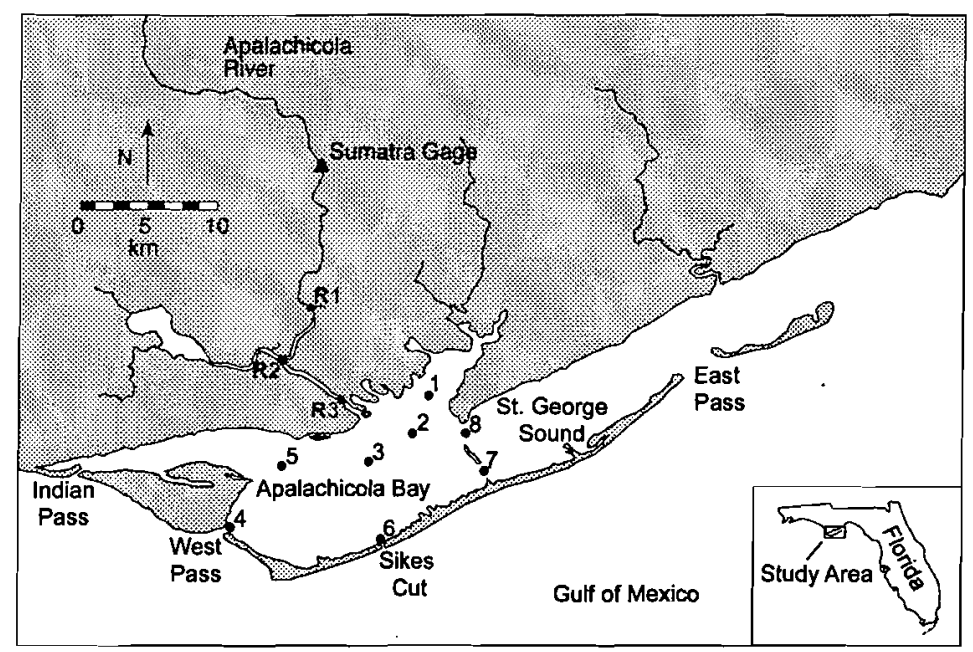

Fig. 1. Location of the sample sites in the Apalachicola Bay and River. Stns 1 through 8 were sampled for nutrients, chl $a$, and primary productivity. River nutrients were collected at Stns R1, R2, and R3
This study provides an analysis of the ecological factors that control phytoplankton production and biomass throughout the year in Apalachicola Bay. Therefore, we collected and analyzed physical, chemical and biological data from the estuary on a monthly basis for a 3 yr period as part of a comprehensive study of the Apalachicola-Chattahoochee-Flint (ACF) River basin (Lewis 1997). Because grazing control of phytoplankton biomass is important in other estuaries, we explored a hypothesis that grazing would be important in Apalachicola Bay. However, the estuary receives large amounts of freshwater from the Apalachicola River, resulting in a short residence time. Therefore, we also explored an alternate hypothesis that export from the estuary, rather than grazing, would provide a significant control on phytoplankton biomass. To test these hypotheses, we applied a general model for estuarine processes developed by Cloern et al. (1985) to these data sets.

\section{METHODS}

Field sample collection. Mean daily river flow was obtained from the U.S. Geological Survey's gage closest to the estuary at Sumatra, Florida, located $32 \mathrm{~km}$ upstream from the river mouth. Monthly measurements of hydrographic, chemical and biological variables were made from March 1993 through May 1996 at 3 Apalachicola River locations and 8 bay stations (Fig. 1). Surface river water samples were collected for nutrient analysis. Both surface and bottom estuarine water samples were collected for nutrient and chl a analyses. Samples were placed in acid-washed polyethylene bottles and kept on ice in the dark for transport to the Apalachicola National Estuarine Research Reserve laboratory where they were filtered.

Determination of in situ variables. Temperature and salinity were measured in situ with a thermistor-equipped $\mathrm{YSI}^{\oplus}$ salinometer. The thermistor was calibrated with the freshwater freezing point.

Submarine PAR was measured with a Li$\mathrm{Cor}^{\circledast}$ model 192SA underwater quanta sensor attached to a deck meter. Surface PAR was measured throughout the sampling period with a Li-Cor ${ }^{\circledast}$ model 192SA quanta sensor connected to a Li-Cor ${ }^{\oplus} \mathrm{LI}-1000$ data logger. The quanta sensors were calibrated at the factory with NBS standard lamps. Solar radiation was measured at the St. George Island Bridge over Apalachicola Bay every half hour with a pyranometer that was maintained by the Northwest Florida Water Management Dis- 
trict. Pyranometer data were converted to PAR values by intercalibration with the Li-Cor ${ }^{\circledR}$ quanta sensor. At each station, the bulk extinction coefficient, $k$, was determined from PAR values measured at several depths.

Determination of chemical variables. Nutrients were analyzed within $24 \mathrm{~h}$ of the sample collection. Nitrate $\left(\mathrm{NO}_{3}{ }^{-}\right)$concentrations were determined with the chemiluminescence detector-based method for trace nitrite $\left(\mathrm{NO}_{2}{ }^{-}\right)$and $\mathrm{NO}_{3}{ }^{-}$in aqueous samples. The method was developed by Cox (1980) and applied to seawater analyses by Garside (1982). We used the modified version of Garside's method (Braman \& Hendrix 1989). Nitrate and $\mathrm{NO}_{2}^{-}$are rapidly reduced by vanadium (III) at 80 to $90^{\circ} \mathrm{C}$ to nitric oxide. Nitric oxide is then removed from the reaction solution by scrubbing with helium carrier gas and is detected with a Thermo Environmental ${ }^{\circledR}$ Model 42 chemiluminescence NOx analyzer connected to a $\mathrm{HP}^{\circledR} 3396$ Series II integrator. Because $\mathrm{NO}_{2}{ }^{-}$is also reduced by this method, the procedure measures $\mathrm{NO}_{3}^{-}+\mathrm{NO}_{2}^{-}$. Nitrite concentrations were measured colorimetrically (Strickland \& Parsons 1972) and subtracted from the $\mathrm{NO}_{3}{ }^{-}+$ $\mathrm{NO}_{2}^{-}$values to yield $\mathrm{NO}_{3}{ }^{-}$concentrations. The $\mathrm{NO}_{3}{ }^{-}+$ $\mathrm{NO}_{2}{ }^{-}$determined with vanadium reduction were always higher than the $\mathrm{NO}_{2}{ }^{-}$concentrations. Ammonium $\left(\mathrm{NH}_{4}^{+}\right)$was determined with the phenol-hypochlorite method as outlined in Strickland \& Parsons (1972). Soluble reactive phosphate $\left(\mathrm{PO}_{4}{ }^{3-}\right)$ was determined by the ascorbic acid-phospho-molybdate method outlined in Strickland \& Parsons (1972).

Total dissolved inorganic carbon (TDIC) concentrations are required for primary productivity calculations. Therefore, surface and bottom estuarine water samples were collected, placed in $50 \mathrm{ml}$ biological oxygen demand bottles, kept on ice in the dark and analyzed within $24 \mathrm{~h}$. TDIC was measured with a flow injection analyses method (Hall \& Aller 1992).

Determination of biological variables. Water samples obtained for pigment analyses were stored on ice in the dark until they were filtered through GF/A filters within $3 \mathrm{~h}$ after collection. The filters were kept frozen in the dark until analyses, which was completed within $5 \mathrm{~d}$. Pigments were extracted from phytoplankton with $90 \%$ acetone for 18 to $24 \mathrm{~h}$ in the dark. The extract optical density was measured spectrophoto-

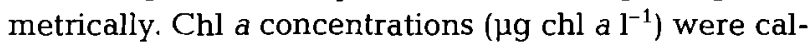
culated with the formula from Strickland \& Parsons (1972).

Except at a few stations located above oyster bars, most of the sample stations were located above flocculent sediment, which had an average 0.7 porosity. The shallow nature of the estuary, together with frequent wind events, daily tidal mixing, and variable river plume excursion patterns, result in high and variable water column turbidity levels. The interaction of these variables resulted in bottom PAR values which ranged from about 5 to $<1 \%$ of surface values at different stations and different times.

Surface and bottom water samples were obtained for productivity measurements at each Apalachicola Bay station (Fig. 1). A PVC Kemmerer bottle equipped with silicon gaskets was used to collect samples. Those features avoid contamination from black neoprene gaskets or closure devices (Fitzwater et al. 1982, Chavez \& Barber 1987, Williams \& Robertson 1989). Duplicate light bottles were filled with water from each sample depth and placed in a light-tight box for transport to Stn 3 (Fig. 1), where productivity incubations were performed.

Immediately prior to incubation, approximately $5 \mu \mathrm{Ci}{ }^{14} \mathrm{C}$-bicarbonate was added to each bottle. The activity of the standard solution was previously determined with the method of Iverson et al. (1976). Bottles were incubated in situ, at depths corresponding to the light level at which they were collected, for approximately $4 \mathrm{~h}$ beginning at 12:00 $\mathrm{h}$ local time. At the end of the incubation period, sample bottles were preserved with $1 \mathrm{ml}$ of $2 \%$ mercuric chloride and immediately placed in the dark.

After incubation, samples were filtered through $\mathrm{GF} / \mathrm{C}$ filters and treated with hydrochloric acid fumes to remove inorganic ${ }^{14} \mathrm{C}$. Filters were placed in liquid scintillation vials after which liquid scintillation cocktail was added to each vial. Radioactivity was measured with a LKB ${ }^{\otimes}$ Wallac Model 1217 liquid scintillation spectrometer and corrected for quenching with the channels ratio procedure (Pugh 1970). Disintegration per minute values were converted to phytoplankton carbon productivity with the formula in Strickland \& Parsons (1972).

Vertically integrated primary productivity was calculated for each station by averaging the surface and bottom productivity values and multiplying the average by the water depth. Primary productivity rates were linearly interpolated to the entire photoperiod with the ratio of daily PAR to PAR measured during the incubation period. Annual phytoplankton production was determined by integration of daily productivity values with the trapezoidal rule (McCracken \& Dorn 1964).

Water export and residence time calculations. Water export from the estuary to the Gulf of Mexico was determined with a 3-dimensional, time-dependent, numerical hydrodynamic model that allowed velocity, temperature and salinity field calculations (Huang \& Jones 1997). A Blumberg \& Mellor (1980, 1987) model application to Apalachicola Bay used an explicit-inhorizontal, implicit-in-vertical, finite-difference scheme with freshwater inflow, tide, and wind stress forcing. The model has been previously applied to Apalachicola Bay (Jones et al. 1994, Jones \& Huang 1996) as well as to other estuaries such as Chesapeake Bay (Blumberg \& 
Goodrich 1990) and Delaware Bay (Galperin \& Mellor 1990). The set of governing equations is given by Blumberg \& Herring (1987). The model solved a coupled system of differential, prognostic equations describing conservation of mass, momentum, heat, and salinity at each of 930 horizontal grids and 5 vertical layers of the computational scheme. A horizontal, orthogonal, curvilinear coordinate system allowed representation of coastline irregularities. A sigma-coordinate system allowed vertical stretching to simulate water level changes in the estuary. A turbulence closure sub-model (Mellor \& Yamada 1982, Galperin et al. 1988), which provides eddy viscosity and eddy diffusivity for vertical mixing, permitted variation in the forcing factors (Huang \& Jones 1997).

The model was calibrated and validated with hydrographic data recorded at $0.5 \mathrm{~h}$ intervals from in situ instruments located throughout the estuary during a 6 mo period (Huang \& Jones 1997). For simulations used in the present analyses, measured river discharge, winds, tides, temperature, and salinity were applied to the model as boundary conditions. The model was used to calculate water inflow and export at the passes. Estuarine water residence time was calculated by dividing the estuary's volume by the sum of water imported to the estuary.
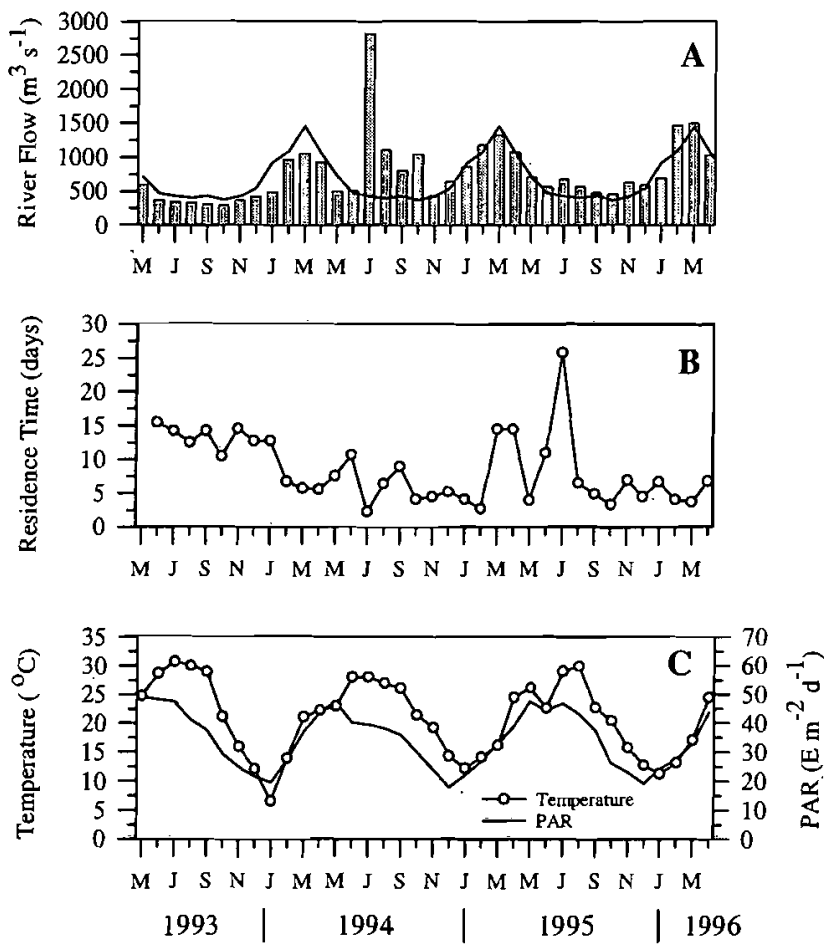

Fig. 2. (A) Monthly mean Apalachicola River flow for the study period (bars) and long-term monthly average flow (solid line) calculated for 1965 to 1989. (B) Estuarine water residence time. (C) Estuarine surface water temperature $(-0)$ and monthly mean PAR values (solid line)

\section{RESULTS}

The long-term Apalachicola River mean discharge (1965 to 1989) is $710 \mathrm{~m}^{3} \mathrm{~s}^{-1}$ (Fu \& Winchester 1994). Mean discharges for 1993, 1994, and 1995 were 695, 938, and $760 \mathrm{~m}^{3} \mathrm{~s}^{-1}$, respectively. River discharge exhibited a pronounced seasonal pattern (Fig. 2A). The discharge maxima occurred in winter and early spring while summer months were usually characterized by discharge minima. The unusually high discharge $\left(2821 \mathrm{~m}^{3} \mathrm{~s}^{-1}\right)$ that occurred in July 1994 (Fig. 2A) was the result of a tropical storm that delivered large amounts of rain throughout the ACF River drainage basin.

Water residence time in Apalachicola Bay is affected by river discharge and water exchange at the passes (Mortazavi et al. 2000). The water residence time in the estuary varied from 2 to $25 \mathrm{~d}$ with a mean of $8.5 \pm 0.9 \mathrm{~d}$ (Fig. 2B). Maxima in water residence time occurred during the summer low flow season while minima occurred during the high river flow season. The unusually low water residence time in July 1994 (2 d) occurred during a period of maximum river discharge (Fig. 2A).

Estuarine water temperature and daily PAR values measured in Apalachicola Bay also exhibited a pronounced seasonal pattern (Fig. 2C). The mean summer and winter temperatures for the 3 sample years were 28 and $14^{\circ} \mathrm{C}$, respectively. The lowest temperature, $6^{\circ} \mathrm{C}$, was recorded in January 1994. Surface and bottom temperatures were similar (Iverson et al. 1997), suggesting that this shallow estuary is relatively wellmixed as a result of wind and tidal action during most of the year. Maxima in PAR values were recorded from April through August of each year (Fig. 2C). There was a 2-fold difference in PAR values between winter and summer months.

Daily river $\mathrm{NO}_{3}{ }^{-}, \mathrm{NO}_{2}{ }^{-}, \mathrm{NH}_{4}{ }^{+}$, and $\mathrm{PO}_{4}{ }^{3-}$ input to Apalachicola Bay for each month of the $3 \mathrm{yr}$ study period were determined by multiplying the mean monthly river concentrations by the mean daily river flow for that month. Mean daily $\mathrm{NO}_{3}{ }^{-}$input $( \pm 1 \mathrm{SE}$ ), for the 3 Yr period was $22700 \pm 2000 \mathrm{~kg} \mathrm{~N} \mathrm{~d}^{-1}(\mathrm{n}=36)$ and ranged from 6400 to $51300 \mathrm{~kg} \mathrm{~N} \mathrm{~d}^{-1}$ (Fig. 3A). The $\mathrm{NO}_{3}{ }^{-}$input pattern closely followed that of the river flow (Fig. 2A). Nitrate input to the estuary increased with increasing river discharge. River nitrogen dynamics are described in more detail in Mortazavi et al. (2000). During the 1993 summer months, $\mathrm{NO}_{3}{ }^{-}$input was below the 3 yr average and increased gradually from $8200 \mathrm{~kg} \mathrm{~N} \mathrm{~d}^{-1}$ in November to $31700 \mathrm{~kg} \mathrm{~N} \mathrm{~d}^{-1}$ in March 1994. From March to June $1994 \mathrm{NO}_{3}{ }^{-}$input decreased rapidly, reaching characteristic summer values. During July 1994 (Fig. 3A), however, nitrogen input was the highest recorded during the study period as a result of the unusual flood event (Fig. 2A), and 

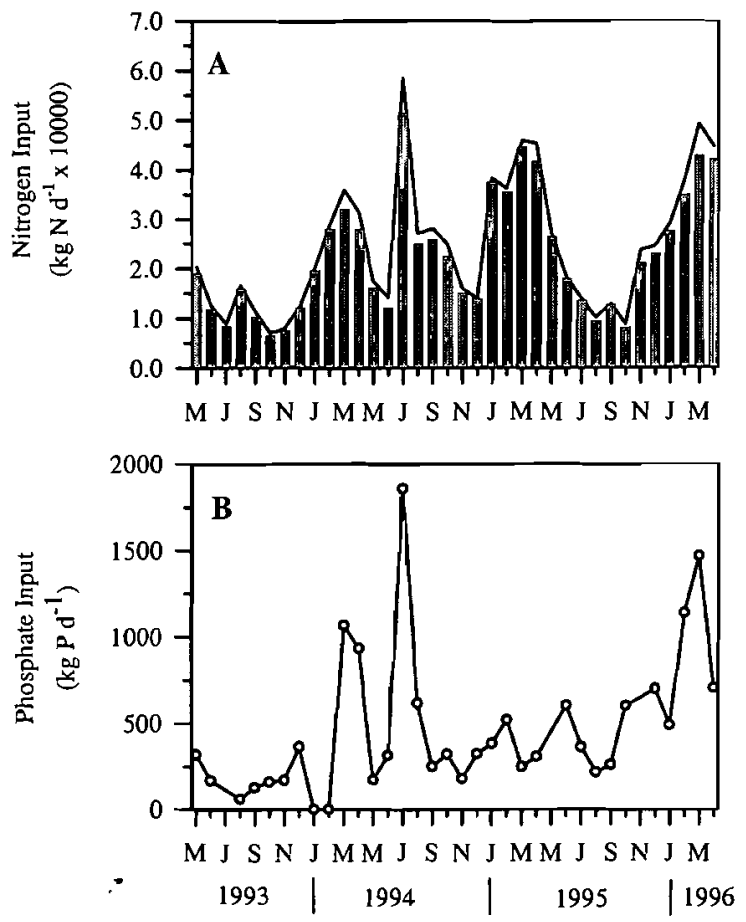

Fig. 3. Input to the estuary of (A) Apalachicola River nitrate (bars) and total DIN (solid line). (B) Apalachicola River soluble reactive phosphate input

remained high throughout the fall. Monthly dissolved inorganic nitrogen (DIN) input rates from May through April of each year were integrated with the trapezoidal rule to produce annual river nitrate input rates to the estuary. DIN input rates for the years 1993-94, 1994-95, and $1995-96$ were $21.7,39.3$, and $31.6 \mathrm{~g} \mathrm{~N} \mathrm{~m}^{-2}$, respectively. On average, $\mathrm{NO}_{3}{ }^{-}$accounted for $93 \%$ of the DIN input. Average $\mathrm{NO}_{3}{ }^{-}$concentrations in the estuary varied from $14 \mathrm{mg} \mathrm{N} \mathrm{m}^{-3}$ during the summer low riverflow period to $280 \mathrm{mg} \mathrm{N} \mathrm{m}^{-3}$ during the winter high river-flow period (Pennock et al. 1999).

The $\mathrm{PO}_{4}{ }^{3-}$ input pattern was not as clear as the $\mathrm{NO}_{3}{ }^{-}$ input pattern. Apalachicola River $\mathrm{PO}_{4}{ }^{3-}$ input to the estuary ranged from undetectable to $1900 \mathrm{~kg} \mathrm{P} \mathrm{d}{ }^{-1}$ (Fig. 3B). Mean river $\mathrm{PO}_{4}{ }^{3-}$ input to the estuary was $465 \pm 73 \mathrm{~kg} \mathrm{Pd} \mathrm{d}^{-1}(\mathrm{n}=33)$. Daily $\mathrm{PO}_{4}{ }^{3-}$ input to the estuary generally increased with increasing river flow although no clear seasonal pattern was evident. Maximum $\mathrm{PO}_{4}{ }^{3-}$ input to the estuary occurred during the July 1994 flood (Fig. 3B). Although river flow had reached characteristic winter maximum values during February 1994 (Fig. 2A), the daily $\mathrm{PO}_{4}{ }^{3-}$ input to the estuary remained low (Fig. 3B). The annual river $\mathrm{PO}_{4}{ }^{3-}$ inputs for the years 1993-94, 1994-95, and 1995-96 were 0.33, 0.61, and $0.85 \mathrm{~g} \mathrm{P} \mathrm{m}^{-2}$, respectively. Average $\mathrm{PO}_{4}{ }^{3-}$ concentrations ( 3.1 to $9.3 \mathrm{mg} \mathrm{P} \mathrm{m}^{-3}$ ) in the estuary generally increased with increasing river flow (Pennock et al. 1999).
Mean surface and bottom chl a values during the study period were $5.3 \pm 0.4$ and $5.6 \pm 0.4 \mu \mathrm{g} \mathrm{chl} \mathrm{a} \mathrm{l}^{-1}$. respectively (Iverson et al. 1997). Chl a concentrations increased with increasing $\mathrm{NO}_{3}{ }^{-}$input from a summer low in 1993 to their highest value in February 1994 (Fig. 4A). This seasonal trend was observed for other periods as well. However, during the 1994 summer flood, estuary chl a concentration decreased and remained low until September (Fig. 4A) despite a 5-fold increase in river $\mathrm{NO}_{3}^{-}$input from 10000 to over $50000 \mathrm{~kg} \mathrm{~N} \mathrm{~d}^{-1}$ (Fig. 3A). By October 1994, river $\mathrm{NO}_{3}^{-}$ input and the estuary chl $a$ concentration had returned to pre-flood values. After October, chl a concentrations increased with increasing river flow and $\mathrm{NO}_{3}{ }^{-}$input to the estuary, until reaching winter maximum values during January 1995 (Fig. 4A). During the summer 1995 and spring 1996 months, $\mathrm{NO}_{3}{ }^{-}$input and chl a patterns were not as regular as during the preceding years.

Temporal patterns of daily phytoplankton productivity for the study period (Fig. 4B) were similar to those observed for Apalachicola Bay during 1972-73 (Estabrook 1973) and for other temperate estuaries (Boynton et al. 1982). Mean daily productivity for the study period was $750 \pm 68 \mathrm{mg} \mathrm{C} \mathrm{m}^{-2} \mathrm{~d}^{-1}(\mathrm{n}=34)$, ranging from 96 to $1812 \mathrm{mg} \mathrm{C} \mathrm{m}^{-2} \mathrm{~d}^{-1}$. Maxima in primary productivity rates were measured in summer months (Fig. 4B), when temperature and PAR values (Fig. 2C)
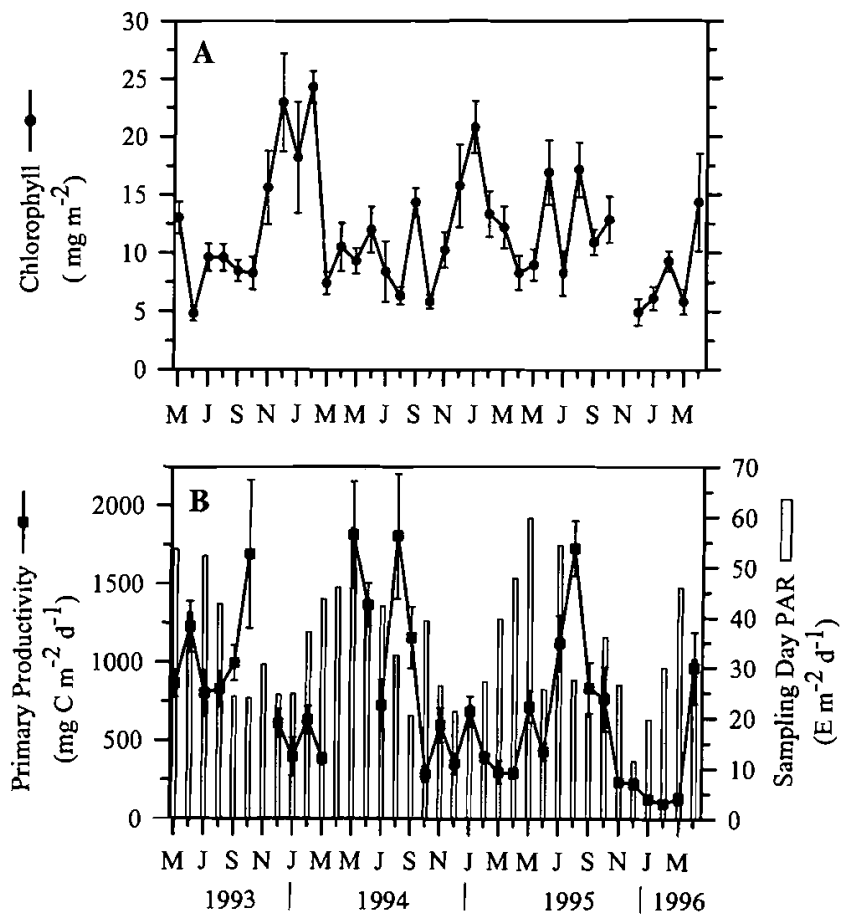

Fig. 4. (A) Apalachicola Bay mean ( $\pm 1 \mathrm{SE}$ ) water column integrated chl $a(\bullet)$. (B) Apalachicola Bay mean $( \pm 1$ SE) daily primarily productivity (a) and sampling day PAR values (shaded bars) 

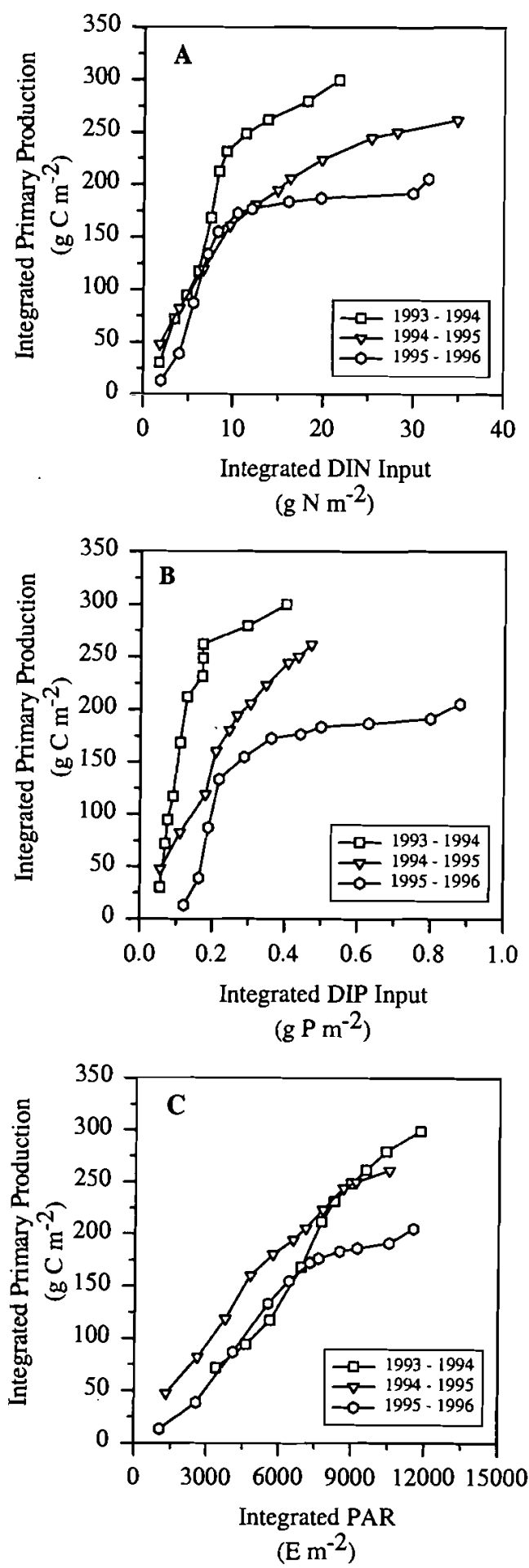

Fig. 5. Integrated primary production as a function of $(\mathrm{A})$ integrated DIN input, (B) integrated $\mathrm{PO}_{4}{ }^{3-}$ input, and (C) integrated PAR. Monthly values for primary productivity, river DIN and $\mathrm{PO}_{4}{ }^{3-}$ input to Apalachicola Bay, and PAR flux were consecutively summed to generate a time-series set of stepwise integrated values. For example, the first data point on each plot represents an integrated value for the period of May through June; the following data point represents integrated value for the period of May through July, etc. were generally high and river nutrient input to the estuary was low (Fig. 3). An exception to this generalization occurred during summer 1994, when nutrient input to the estuary reached unusually high values (Fig. 3) as the result of a major flood event (Fig. 2A). During July 1994, despite high nutrient availability, estuarine primary productivity decreased substantially compared to the pre-flood rates although temperature and PAR values were typical of summer months (Figs. 2B \& 4B).

Minima in primary productivity were observed during winter, coincident with lowest temperature and PAR values (Fig. 4B). Productivity maxima varied among years with annual peaks in October 1993, May and August 1994 and August 1995. Mean integrated annual production values for 1993, 1994 and 1995 were $300 \pm 54,261 \pm 45$, and $205 \pm 34 \mathrm{~g} \mathrm{C} \mathrm{m}^{-2}$, respectively. These standard error values were estimated by error propagation throughout each annual period with the method of Morel \& Andre (1991).

Phytoplankton productivity, river DIN and $\mathrm{PO}_{4}{ }^{3-}$ input, and PAR levels all exhibit pronounced temporal variability in Apalachicola Bay. Time-series analyses of Apalachicola River flow indicated long-term cycles with periods between 5 and 7 yr (Meeter et al. 1979). The data acquired in this study were not acquired over a time period long enough to satisfy the Nyquist sampling theorem (Jenkins \& Watts 1968). Therefore, an alternate approach was devised to analyze the temporal progression of several variables. Monthly values for primary productivity, river DIN and $\mathrm{PO}_{4}{ }^{3-}$ input to Apalachicola Bay, and PAR flux were first consecutively summed to generate a time-series set of stepwise integrated values. After that procedure was completed, integrated primary production values were plotted as a function of each of the other integrated variables.

Integrated primary production increased with increasing DIN input (Fig. 5A), $\mathrm{PO}_{4}{ }^{3-}$ input (Fig. 5B), and PAR (Fig. 5C). However, patterns in integrated values for each variable differed among years. The increase in integrated primary production in response to integrated DIN input had a change in slope each year at approximately $10 \mathrm{~g} \mathrm{~N} \mathrm{~m}^{-2}$ (Fig. 5A). Integrated primary production increased in response to integrated $\mathrm{PO}_{4}{ }^{3-}$ input values for all 3 years, but exhibited changes in slope only during 1993-94 and 1995-96 (Fig. 5B). Similarly, integrated primary production increased with increasing integrated PAR values (Fig. $5 \mathrm{C}$ ). The trend, however, exhibited less interannual variability compared to the trend of primary production with increasing nutrient input values.

Interannual variability in primary production response to DIN input, $\mathrm{PO}_{4}{ }^{3-}$ input, and to PAR (Fig. 5) precluded direct intercomparison of data trends 
among years and between time periods with different river-flow conditions. Therefore, a normalization procedure was applied to the monthly step-wise integrated data to aid in identifying and comparing patterns in the data. Monthly mean primary productivity values were divided by annually integrated production to represent the fraction of annual production realized during that month. Each monthly fraction was then added to the fraction determined for the previous months to generate a set of normalized, step-wise, integrated values. The same treatment was applied to river DIN and $\mathrm{PO}_{4}{ }^{3-}$ input, and PAR data. Normalized integrated primary production was plotted as a function of normalized integrated DIN input (Fig. 6A), $\mathrm{PO}_{4}{ }^{3-}$ input (Fig. 6B), and PAR values (Fig. 6C). The normalized integrated data were examined for the low-flow period (May to November) and the high-flow period (December to April). These 2 periods were delineated based on an analyses of the $32 \mathrm{yr}$ mean Apalachicola River flow conditions (Fu \& Winchester 1994).

Normalized integrated estuarine primary production increased linearly as a function of normalized integrated DIN (Fig. 6A), normalized integrated $\mathrm{PO}_{4}{ }^{3-}$ (Fig. 6B), and PAR (Fig. 6C) during both time periods. However, the increase during December to April had a lower slope, compared to the increase during May to November, for each of the variables. This is a result of primary productivity rates that were lower during December to April than during May to November (Fig. 4B). Over $75 \%$ of Apalachicola Bay annual phytoplankton production occurred from May to November, while river nutrient input and PAR during this period accounted for only 40 and $60 \%$ of their annual integrated values, respectively.

\section{DISCUSSION}

\section{Apalachicola Bay phytoplankton production, chlorophyll, and nutrient history}

On an annual scale, Apalachicola River DIN input, $\mathrm{PO}_{4}{ }^{3-}$ input, mean estuarine primary production, and chl a concentrations averaged $30.9 \pm 5.1 \mathrm{~g} \mathrm{~N} \mathrm{~m}^{-2}, 0.60 \pm$ $0.15 \mathrm{~g} \mathrm{P} \mathrm{m}^{-2}, 255 \pm 78 \mathrm{~g} \mathrm{C} \mathrm{m}^{-2}$ and $11.84 \pm 0.8 \mathrm{mg} \mathrm{chl} \mathrm{a}$ $\mathrm{m}^{-2}$, respectively, for $3 \mathrm{yr}$ beginning with 1993. These primary production and chl a values are sinilar to those reported for an annual period extending from 1972 to 1973 (Estabrook 1973), when primary production and estuarine mean chl $a$ were $191 \mathrm{~g} \mathrm{C} \mathrm{m}^{-2}$ and $12.4 \mathrm{mg} \mathrm{chl} \mathrm{a} \mathrm{\textrm {m } ^ { - 2 }}$, respectively. Apalachicola River $\mathrm{NO}_{3}{ }^{-}$input to the estuary was $22 \mathrm{~g} \mathrm{~N} \mathrm{~m}^{-2}$ during 1972-73. Annual phytoplankton production and biomass were similar between the early 1970s and 1990s, although annual $\mathrm{NO}_{3}{ }^{-}$input to Apalachicola Bay increased by $36 \%$ over 2 decades. Sixty percent of river $\mathrm{NO}_{3}{ }^{-}$input to the estuary occurred in the November to April period, during which time water residence time
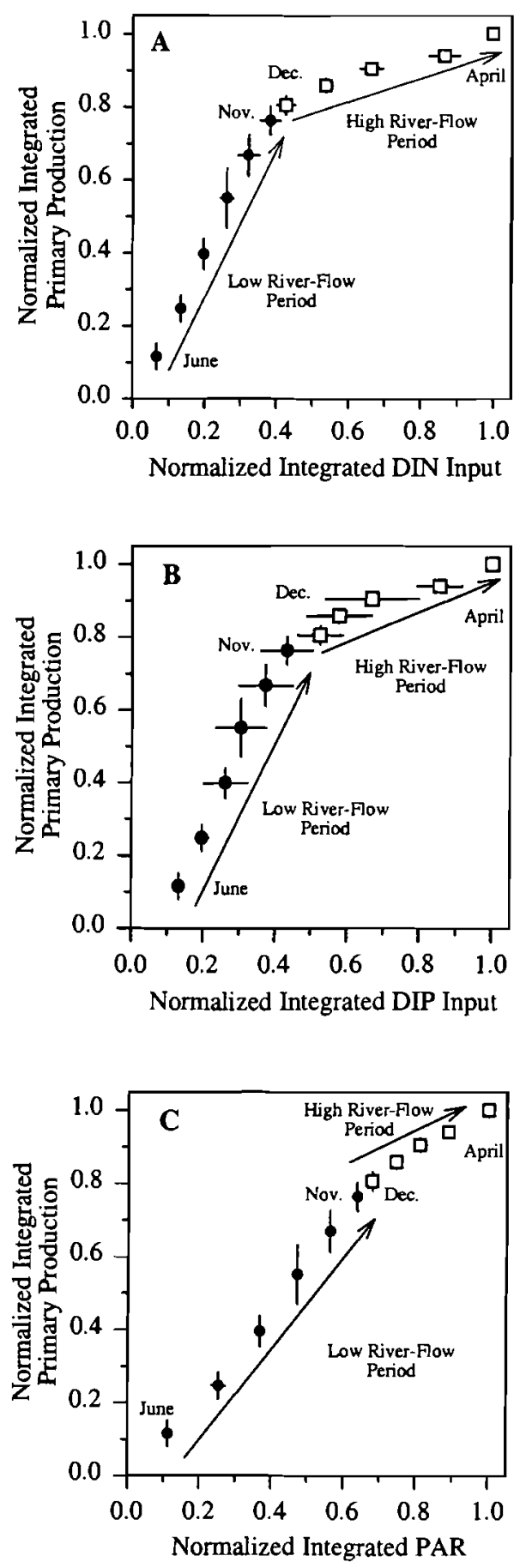

Fig. 6. Normalized integrated primary production as a function of normalized (A) integrated DIN input, (B) integrated $\mathrm{PO}_{4}{ }^{3-}$ input, $(\mathrm{C})$ integrated PAR. May to November (-) and December to April ( $\square$ ) are represented. The arrows indicate progression with time 
was low (Fig. 2B) and only $25 \%$ of the annual primary production was realized (Fig. 6A). The greater fraction of annual $\mathrm{NO}_{3}{ }^{-}$input occurs during short residence time periods and is not retained in the estuary long enough to be processed by the primary producers (Mortazavi et al. 2000).

\section{Factors affecting estuarine phytoplankton biomass production and retention}

Apalachicola Bay phytoplankton production and biomass are similar in magnitude to values measured in Mobile Bay and Fourleague Bay, other river-dominated estuaries which discharge into the northern Gulf of Mexico (Pennock et al. 1999). In contrast, annual nitrogen and phosphorus input to Apalachicola Bay are lower than the input rates to those estuaries (Twilley et al. 1999). This could result from Apalachicola River flow rates, which are significantly lower than the flow rates of rivers that supply nutrients to Mobile Bay and Fourleague Bay (Bianchi et al. 1999).

In contrast, Apalachicola Bay and Chesapeake Bay have comparable mean annual DIN input rates (Boynton et al. 1995), yet significantly different residence times (Nixon et al. 1996) and primary production (Kemp et al. 1997). The Chesapeake Bay water residence time is 8 mo (Nixon et al. 1996), significantly longer than the average $8.5 \mathrm{~d}$ residence time for Apalachicola Bay. Primary production in the Chesapeake Bay mainstem exceeds Apalachicola Bay primary production by 2.5 times (Kemp et al. 1997). Nutrient input to Chesapeake Bay associated with river inflow is retained in the estuary (Nixon et al. 1996) for time periods long enough to support large rates of primary production. In contrast, $66 \%$ of annual nutrient input to Apalachicola Bay is exported to the Gulf of Mexico, and is not retained for time periods long enough to support large rates of phytoplankton production (Mortazavi et al. 2000).

Zooplankton grazing significantly impacts estuarine phytoplankton standing stock and productivity. In the Strait of Georgia, grazing was the primary factor controlling phytoplankton biomass throughout the year (Stockner et al. 1979). During the spring, grazing removed all of the daily phytoplankton productivity in Halifax Harbour (Gifford 1988). In the estuarine portion of the Mississippi River mouth, the copepod community removed $4 \%$ of primary production in May and $62 \%$ in September (Dagg 1995b). Zooplankton consumed nearly half of Hudson River estuarine primary productivity during the fall (Lonsdale et al. 1996a) and between 23 and $52 \%$ of phytoplankton production during the spring and summer in Long Island Bays (Lonsdale et al. 1996b). Microzooplankton consume
$83 \%$ of annual phytoplankton production in Mobile Bay (Lehrter et al. 1999).

Following winter-spring river $\mathrm{NO}_{3}{ }^{-}$input to Chesapeake Bay, chl a concentration increased to bloom levels (Malone et al. 1988, Harding 1994). This resulted from low zooplankton grazing pressure, which removed between 23 and $41 \%$ of daily phytoplankton productivity during this period (Malone 1992). However, zooplankton grazing became the dominant factor controlling phytoplankton biomass during summer months, removing between 31 and $161 \%$ of Chesapeake Bay phytoplankton productivity (Malone 1992).

Based on a general model, Cloern et al. (1985) evaluated processes which controlled the seasonal progression of phytoplankton productivity and biomass in several reaches of San Francisco Bay. In that application, the general model was simplified to include 3 rates: phytoplankton specific growth rate, zooplankton grazing rate, and an aggregate of phytoplankton sinking, benthic grazing, and transport processes. Phytoplankton specific growth rate was estimated from primary productivity, while zooplankton grazing was determined with an Ivlev (1945) function applied to zooplankton abundance. The temporal importance of the aggregated factor set was inferred from calculation results.

The processes that interact to control estuarine phytoplankton biomass in Apalachicola Bay can be described with a reduced equation derived from the general model of Cloern et al. (1985):

$$
\frac{\partial B}{\partial t}=B \times(\mu-m-S-\varepsilon)
$$

where $B$ is mean estuarine $\mathrm{chl} a\left(\mathrm{mg} \mathrm{m}^{-2}\right)$, $\mu$ is phytoplankton growth rate, $m$ is estuarine community grazing rate, $S$ is chl a burial rate, and $\varepsilon$ the fraction of water exported from the estuary on a daily basis. The rates in Eq. (1) have units $d^{-1}$ and are time-variable. We used an empirical treatment to calculate the magnitudes of process rates that affect monthly mean chl a concentrations in Apalachicola Bay through an annual period. The rates were determined as follows:

The large detritus content of Apalachicola Bay waters precluded determination of the phytoplankton $\mathrm{chl} a$ to carbon ratio (chl:C) ratio from chl $a$ and particulate organic carbon measurements. Therefore, phytoplankton growth rates were estimated from the ratio of daily carbon productivity multiplied by a constant 1:50 chl:C ratio, similar to that employed by Cloern et al. (1985) for San Francisco Bay, by Dagg (1995b) for the estuarine portion of the Mississippi River plume and by Lehrter et al. (1999) for Mobile Bay. Phytoplankton growth rates calculated in this fashion were compared with those determined from the Eppley (1972) equa- 

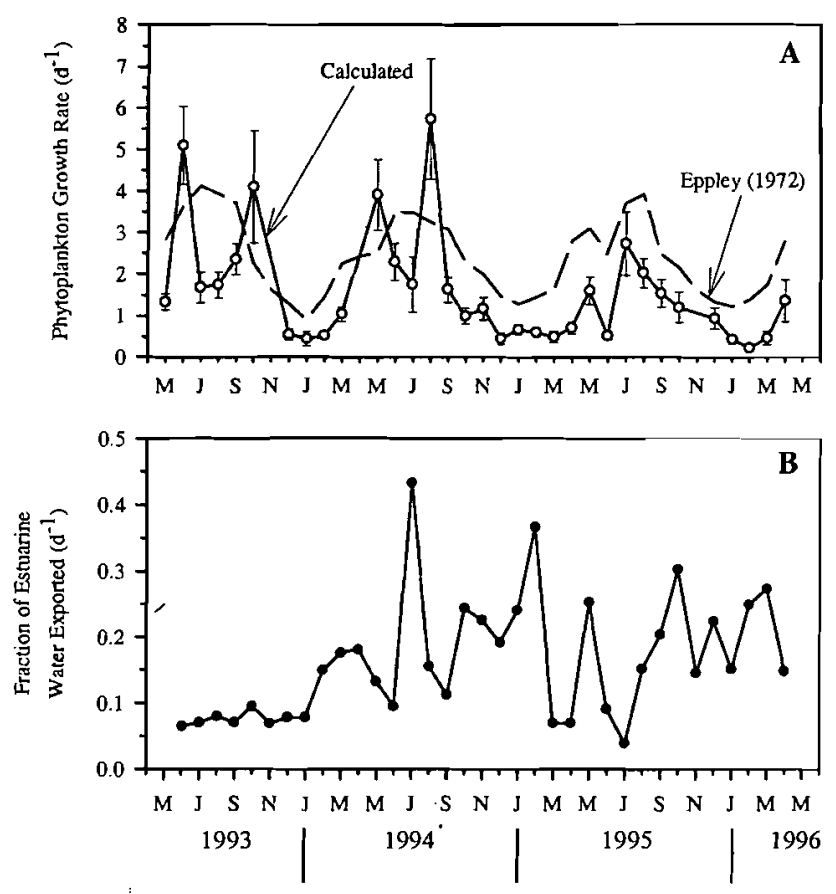

Fig. 7. (A) Phytoplankton growth rate from Eppley (1972) water temperature dependent equation (dashed line) and calculated growth rate ( $\pm 1 \mathrm{SE}$ ) from primary productivity and chl a data $(0)$. Growth rates greater than those determined from Eppley's were within 2 SE. (B) Fraction of bay volume exported on a daily basis

tion as a metric to assess the veracity of the calculations. Growth rates calculated from Apalachicola Bay data exhibited a pattern similar to those obtained from application of Eppley's (1972) equation to Apalachicola Bay water temperature data (Fig. 7A), but were usually lower than predicted from Eppley's (1972) function. However, Eppley's (1972) equation was obtained for unicellular algal cultures grown under nutrient-replete conditions and continuous light. Therefore, that equation describes maximum potential growth rates under unlimited environmental conditions. The comparison in Fig. 7A suggests that since the growth rates determined for the Apalachicola Bay data do not exceed or are within 2 SE of the rates determined from Eppley's function, a 1:50 chl:C ratio is adequate for Eq. (1) application to Apalachicola Bay data. Therefore, we multiplied mean daily carbon productivity between time intervals by a constant $1: 50 \mathrm{chl}$ : $\mathrm{C}$ ratio to calculate daily chl a production (Fig. 8A).

The estimated $\varepsilon$ was based on numerical model residence time calculations described above. Chl a loss through export from the estuary was calculated by multiplying mean daily water export by mean estuarine chl a magnitude between 2 time intervals. The calculated export rate (Fig. 7B) from the estuary to the Gulf was relatively small compared to $\mu$ (Fig. 7A).
Phytoplankton sinking in a stratified, deep estuary would represent a net loss from the euphotic zone. However, conditions are different in the shallow Apalachicola Bay, where winds and tides continually mix the water column. Two different methods are available for estimating phytoplankton loss from the water column through sinking and burial. Burial represents a time-integrated biomass loss that is used in Eq. (1) as equivalent to sinking loss. The annual nitrogen burial rate for the estuary was $24 \mathrm{mg} \mathrm{N} \mathrm{m}^{-2} \mathrm{~d}^{-1}$ (Mortazavi et al. 2000). Some nitrogen burial occurs after transport of particulate organic material into the estuary from the Apalachicola River. If chl:C equals $1: 50$, and $C: N$ is 5.7 by weight (Redfield 1958), then for $24 \mathrm{mg} \mathrm{N} \mathrm{m} \mathrm{m}^{-1}$ sedimentation rate, the average of annually integrated chl a burial $(B \times S)$ is equivalent to $2.7 \mathrm{mg}$ chl $a \mathrm{~m}^{-2} \mathrm{~d}^{-1}$.

Alternately, phytoplankton biomass which sinks to the sediment may not be buried, but may be completely remineralized. Under that condition, a linear regression equation for benthic remineralization as a function of the sum of water column primary production and organic carbon input, obtained by Nixon (1982), can be applied to Apalachicola Bay. Mattraw \& Elder (1984) estimated particulate carbon input to the estuary as $3.510^{10} \mathrm{~g} \mathrm{C} \mathrm{yr}^{-1}$, or $369 \mathrm{mg} \mathrm{C} \mathrm{m}^{-2} \mathrm{~d}^{-1}$. Applying the Nixon (1982) relation to the Apalachicola Bay primary productivity, $699 \mathrm{mg} \mathrm{C} \mathrm{m} \mathrm{m}^{-2}$, and particulate organic input, an estimated $260 \mathrm{mg} \mathrm{C} \mathrm{m}^{-2} \mathrm{~d}^{-1}$, is remineralized. If we assume that all the carbon remineralized originated from phytoplankton, applying a 1:50 chl:C ratio this rate would correspond to $5.9 \mathrm{mg}$ chl a $\mathrm{m}^{-2} \mathrm{~d}^{-1}$ remineralized in the benthos. However, this rate is an upper limit because not all carbon remineralized in the sediment originates from phytoplankton. Inspection of Fig. 8A suggests that a maximum of $5.9 \mathrm{mg} \mathrm{chl} \mathrm{a}$ $\mathrm{m}^{-2} \mathrm{~d}^{-1}$ loss through sedimentation is similar in magnitude to chl a loss through export in most months.

The daily change in mean estuarine chl a magnitude is the result of 4 different rates interacting in Eq. (1). Because $\mu, \varepsilon$, and the change in daily mean estuarine chl $a$ are calculated, the combined chl a loss caused by grazing plus sedimentation can be algebraically determined for each time period. As a result of these calculations, chl a loss by grazing plus sedimentation was greatest during summer months and least during winter months (Fig. 8A). However, because mean chl a sedimentation rate is low, the grazing rate accounted for most of the chl a loss during most months of the year.

A sensitivity analysis, performed by changing the chl:C ratio, showed that variations in the ratio changed the magnitude, but not the pattern of grazing influence on chl a loss from the estuary. As the chl:C ratio increased from $1: 75$, to $1: 50$, to $1: 25$, grazing removed 

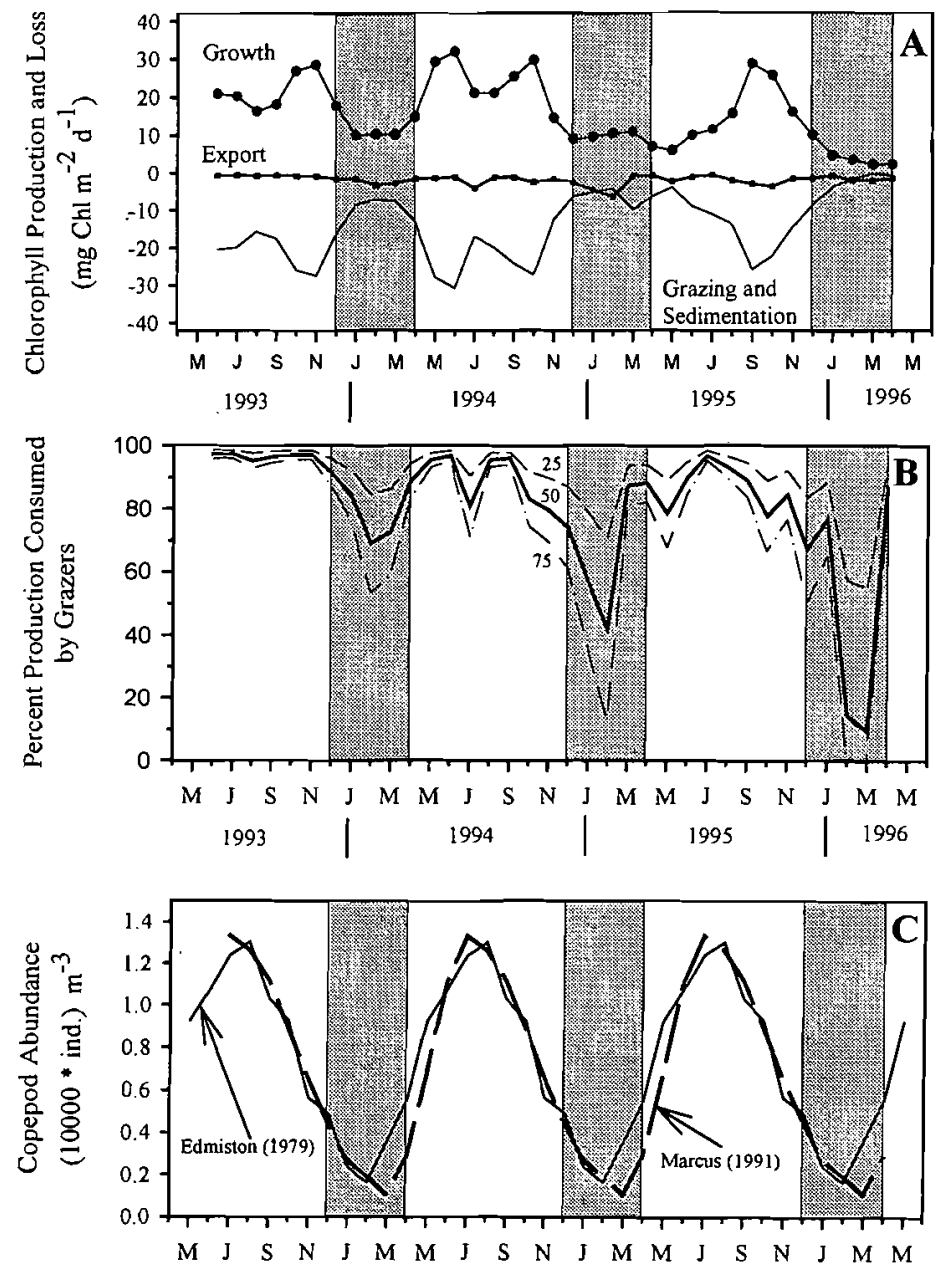

Fig. 8. (A) Calculated chlorophyll production and loss through export. Loss through sedimentation and grazing were determined with Eq. (1). (B) Percent production consumed by grazers. The numbers next to each line on the plot represent chl:C ratio of 1:25, 1:50, and 1:75. (C) Mean zooplankton abundance, calculated from 2 separate 1 yr monitorings (Edmiston 1979, Marcus 1991) and extrapolated to 3 consecutive years with a 3 mo running mean procedure. The shaded bars corresponds to the long-term high river-flow periods

an increasingly greater fraction of phytoplankton biomass than did export (Fig. 8B).

Chl a loss from the estuary through export was always less than the loss through grazing plus sedimentation, except in the winters of 1994-95 and 199596 when export became the dominant loss term. Chl a export was more important than grazing in biomass control during winter 1994-95 compared to winter 1993-94, when water export was lower (Fig. 7B). However, during the 1995-96 winter, a combination of higher export (Fig. 7B) and very low primary productivity resulted in a greater effect of export compared to grazing on phytoplankton biomass loss from the estuary (Fig. 8A). On an annual basis, grazing accounted for an average $80 \%$ of chl a loss. This rate is similar to that determined $(83 \%)$ for Mobile Bay (Lehrter et al. 1999), a river-dominated estuary west of Apalachicola Bay.

Zooplankton numbers exhibited a seasonal cycle in Apalachicola Bay (Edmiston 1979, Marcus 1991) (Fig. 8C). Macrozooplankton abundance was maximum during summer when Apalachicola River flow and estuarine water export were minimum, and primary productivity was greatest (Fig. 4B). Acartia tonsa is the most abundant planktonic herbivorous copepod in Apalachicola Bay throughout the year, with copepodite life-history stages present in quantities approximately 7 -fold greater than adult copepod numbers at any time (Marcus 1991). The lowest $A$. tonsa numbers were measured from December through February, coincident with low water temperature, high river discharge and high water export from the estuary. Microzooplankton and macrozooplankton abundances generally exhibit the same season patterns in other estuaries (Lonsdale et al. 1996b, Ayukai \& Miller 1998). However, estuarine microzooplankton community grazing pressure generally exceeds that of the macrozooplankton community (Boynton et al. 1995, Dagg 1995a). Based on zooplankton abundance patterns, phytoplankton loss to grazers is expected to be lower during winter compared to the summer months.

In October and December 1998, we measured total zooplankton community grazing with the Landry \& Hassett (1982) dilution technique. The percent of phytoplankton production consumed by the zooplankton grazing community in October 1998 was $98 \%$ and decreased to $28 \%$ in December 1998 . This trend was consistent with results of calculations made with Eq. (1) and data obtained from Apalachicola Bay.

However, herbivorous grazing in Apalachicola Bay is performed by organisms located both in the water column and the benthos. Oysters represent the major component of the benthic herbivores. Between 0.8 and 2.5 million $\mathrm{kg}$ wet weight of oysters are harvested each year (Wilber 1992). Chl a loss through oyster grazing can be determined from oyster nitrogen composition, $7.7 \%$ by weight (Vinogradov 1953), a phytoplankton biomass $\mathrm{C:N}$ ratio of 5.7 and a $\mathrm{C:chl}$ ratio of $50: 1$, an oyster production estimate and a simple food-chain model calculation. Apalachicola Bay has an average $255 \mathrm{~g} \mathrm{C} \mathrm{m}^{-2} \mathrm{yr}^{-1}$ phytoplankton production. Average carbon transfer efficiency between trophic levels is $16 \%$ at that primary production level (Iverson 1990). However, primary production is distributed to several 
grazer components within the estuary. Therefore, as a conservative upper limit we assume a $10 \%$ carbon transfer efficiency from phytoplankton to oysters for use in determining a maximum potential oyster grazing rate. Working backwards from oyster harvest (which is assumed to represent annual oyster production), and applying these conversion factors, oyster grazing accounts for chl a loss ranging from 0.7 to 2.3 $\mathrm{mg} \mathrm{chl} a \mathrm{~m}^{-2} \mathrm{~d}^{-1}$. This range represents 5 to $16 \%$ of daily chl a loss in Apalachicola Bay. Alternatively, if oyster production is assumed to be twice human harvest, the range increases to from 10 to $32 \%$ of daily chl $a$ loss. Therefore, most of chl a loss to grazers occurs in the Apalachicola Bay water column.

\section{CONCLUSIONS}

We examined temporal patterns of river nutrient input to Apalachicola Bay, primary productivity, and chl a. Examination of normalized integrated nutrient and primary production data revealed a temporal decoupling between nutrient input to the estuary and primary production. Approximately $75 \%$ of the primary production occurs from May through November of each year during a period when $40 \%$ of the annual DIN and $\mathrm{PO}_{4}{ }^{3-}$ input values to the estuary occur.

We used the results of a 3-dimensional hydrodynamic model of the estuary, combined with chl a concentrations and primary productivity, to determine the relative importance of export and grazing in controlling phytoplankton biomass in the estuary. The results demonstrate that an average $80 \%$ of the daily chl $a$ is consumed by grazers, with most of the consumption occurring in the water column. Apalachicola Bay is a short residence-time, river-dominated estuary. However, grazing rather than chl a export from the estuary controls phytoplankton biomass levels within the estuary.

Acknowledgements. This research was supported by a grant awarded to R.L.I. and W.M.L. from the Northwest Florida Water Management District and the Florida Department of Environmental Protection. This paper is part of a dissertation submitted to the Department of Oceanography, Florida State University, by B.M. in partial fulfillment of a PhD degree. Many thanks to J. Moss, C. Bailey, L. Edmiston, Rodney Powell, and the staff of the Apalachicola National Estuarine Research Reserve for their assistance. This manuscript benefited from numerous helpful suggestions of 3 anonymous reviewers.

\section{LITERATURE CITED}

Ayukai T, Miller D (1998) Phytoplankton biomass, production and grazing mortality in Exmouth Gulf, a shallow embayment on the arid, tropical coast of Western Australia. J Exp Mar Biol Ecol 225:239-251
Bianchi TS, Pennock JR, Twilley RR (1999) Biogeochemistry of Gulf of Mexico estuaries: implications for management. In: Bianchi TS, Pennock JR, Twilley RR (eds) Biogeochemistry of Gulf of Mexico estuaries. John Wiley \& Sons, New York, p 407-421

Blumberg AF, Goodrich DM (1990) Modeling of windinduced destratification in Chesapeake Bay. Estuaries 13 $236-249$

Blumberg AF, Herring $\mathrm{J}$ (1987) Circulation modeling using orthogonal curvilinear coordinates. In: Nihoul JCJ, Jamart BM (eds) Three dimensional models of marine and estuarine dynamics. Elsevier, Amsterdam, p 55-58

Blumberg AF, Mellor GL (1980) A coastal ocean numerical model. Hamburg. ln: Sundermann J, Holz KP (eds) Mathematical modeling of estuarine physics. Proceedings of the International Symposium 24-26 August, 1978. SpringerVerlag, Berlin, p 203-214

Blumberg AF, Mellor GL (1987) A description of a threedimensional coastal circulation model. In: Heaps NS (ed) Three-dimensional coastal ocean models. Coastal and estuarine sciences, Vol 4. American Geophysical Union, Washington, DC, p 1-16

Boynton WR, Kemp WM, Keefe CW (1982) A comparative analyses of nutrients and other factors influencing estuarine phytoplankton production. In: Kennedy VS (ed) Estuarine comparisons. Academic Press, New York, p 69-88

Boynton WR, Garber JH, Summers R, Kemp WM (1995) Inputs, transformation, and transport of nitrogen and phosphorus in Chesapeake Bay and selected tributaries. Estuaries 18:285-314

Braman RS, Hendrix SA (1989) Nanogram nitrite and nitrate determination in environmental and biological materials by vanadium (III) reduction with chemiluminescence detection. Anal Chem 61:2715-2718

Chavez FP, Barber RT (1987) An estimate of new production in the equatorial Pacific. Deep-Sea Res 34:1229-1243

Cloern JE, Cole BE, Wong RLJ, Apline AE (1985) Temporal dynamics of estuarine phytoplankton: a case study of San Francisco bay. Hydrobiologia 129:153-176

Cox RD (1980) Determination of nitrate and nitrite at the parts per billion level by chemiluminescence. Anal Chem 52: 332-335

Dagg MJ (1995a) Ingestion of phytoplankton by the microand mesozooplankton communities in a productive subtropical estuary. J Plankton Res 17:845-857

Dagg MJ (1995b) Copepod grazing and the fate of phytoplankton in the northern Gulf of Mexico. Cont Shelf Res 15:1303-1317

Edmiston HL (1979) The zooplankton of the Apalachicola Bay system. MSc thesis, Florida State University, Tallahassee

Eppley R (1972) Temperature and phytoplankton growth in the sea. Fish Bull 70:1063-1085

Estabrook RH (1973) Phytoplankton ecology and hydrology of Apalachicola Bay. MSc thesis, Florida State University, Tallahassee

Fitzwater SE, Knauer GA, Martin JH (1982) Metal contamination and its effects on primary production measurements. Limnol Oceanogr 27:544-551

Fu JM, Winchester JW (1994) Sources of nitrogen in three watersheds of northern Florida, USA: mainly atmospheric deposition. Geochim Cosmochim Acta 58:1581-1590

Fulmer JM (1997) Nutrient enrichment and nutrient input to Apalachicola Bay, Florida. MSc thesis, Florida State University, Tallahassee

Galperin B, Mellor GL (1990) A time-dependent, 3-dimensional model of the Delaware Bay and River system. 2. 
3-dimensional flow-fields and residual circulation. Estuar Coast Shelf Sci 31:255-281

Galperin B, Kantha LH, Hassid S, Rosati A (1988) A quasiequilibrium turbulent energy model for geophysical flows. J Atmos Sci 45:55-62

Garside C (1982) A chemiluminescent technique for the determination of nanomolar concentration of nitrate and nitrite in seawater. Mar Chem 11:159-167

Gifford DJ (1988) lmpact of grazing by microzooplankton in the northwest arm of Halifax Harbour, Nova Scotia. Mar Ecol Prog Ser 47:249-258

Hall POJ, Aller RC (1992) Rapid, small-volume, flow injection analyses for $\Sigma \mathrm{CO}_{2}$ and $\mathrm{NH}_{4}{ }^{+}$in marine and freshwaters. Limnol Oceanogr 37:1113-1119

Harding LW. Jr (1994) Long-term trends in the distribution of phytoplankton in Chesapeake Bay: roles of light, nutrients and streamflow. Mar Ecol Prog Ser 104:267-291

Hecky RE, Kilham P (1988) Nutrient limitation of phytoplankton in freshwater and marine environments: a review of recent evidence on effects of enrichment. Limnol Oceanogr 33:796-822

Houde ED, Rutherford ES (1993) Recent trends in estuarine fisheries: predictions of fish production and yield. Estuaries 16:161-176

Huang W, Jones WK (1997) Three-dimensional modeling of circulation and salinity for the low river flow season in Apalachicola Bay, Florida. Northwest Florida Water Management District Water Resources Special Report, Havana, Florida

Iverson RL (1990) Control of marine fish production. Limnol Oceanogr 35:1593-1604

lverson RL, Bittaker HF, Myers VB (1976) Loss of radiocarbon in direct use of aquasol for liquid scintillation counting of solutions containing ${ }^{14} \mathrm{C}-\mathrm{NaHCO}_{3}$. Limnol Oceanogr 21 : $756-758$

Iverson RL, Landing W, Mortazavi B, Schaefer GD, Fulmer JM (1997) Nutrient transport and primary productivity in the Apalachicola River and Bay. Northwest Florida Water Management District Draft final report to the ACF/ACT Comprehensive Study, Havana, Florida

lvlev VS (1945) The biological productivity of waters. Usp Sovrem Biol 19:98-120

Jenkins GM, Watts DG (1968) Spectral analyses and its application. Holden-Day, San Francisco

Jones WK, Huang W (1996) Modeling changing freshwater delivery to Apalachicola Bay, Florida. New York. In Spaulding ML, Cheng RT (eds) Estuarine and coastal modeling. Proceedings of the 4th International Conference 1996. American Society of Civil Engineering, New York, p 116-127

Jones WK, Galperin B, Weisberg RH, Wu TS (1994) Influence of Sikes Cut on Apalachicola Bay, FL: a preliminary analy. sis from a three-dimensional perspective. In: Spaulding ML, Bedford K, Blumberg A, Cheng RT, Swanson C (eds) Estuarine and coastal modeling. Proceedings of the 3rd International Conference 1994. American Society of Civil Engineering, New York, p 351-355

Kemp WM, Smith EM, Marvin-DiPasquale M, Boynton WR (1997) Organic carbon balance and net metabolism in Chesapeake Bay. Mar Ecol Prog Ser 150:229-248

Landry MR, Hassett RP (1982) Estimating the grazing impact of marine micro-zooplankton. Mar Biol 67:283-288

Lehrter JC, Pennock JR, McManus GB (1999) Microzooplankton grazing and nitrogen excretion across a surface estuarine-coastal interface. Estuaries 22:113-125

Lewis FG (1997) Apalachicola River and Bay water demand element: summary and integration of Apalachicola Bay studies. Northwest Florida Water Management District Draft final report to the ACF/ACT Comprehensive Study, Havana, Florida

Livingston RJ (1984) The ecology of the Apalachicola Bay system: an estuarine profile. US Fish and Wildlife Services FWS/OSB-82/05, Washington, DC

Lonsdale DJ, Cosper EM, Doall M (1996a) Effects of zooplankton grazing on phytoplankton size-structure and biomass in the lower Hudson River estuary. Estuaries 19: 874-889

Lonsdale DJ, Cosper EM, Kim WS, Doall M, Divadeenam A, Jonasdottir SH (1996b) Food web interactions in the plankton of Long Island bays, with preliminary observations on brown tide effects. Mar Ecol Prog Ser 134:1-3

Malone TC (1992) Effects of water column processes on dissolved oxygen, nutrients, phytoplankton and zooplankton. In: Smith DE, Leffler M, Mackiernan G (eds) Oxygen dynamics in the Chesapeake Bay: a synthesis of recent research. Maryland Sea Grant, College Park, MD, p 61-112

Malone TC, Crocker LH, Pike SE, Wendler BW (1988) Influence of river flow on the dynamics of phytoplankton production in a partially stratified estuary. Mar Ecol Prog Ser 48:235-249

Malone TC, Conely DJ, Fisher TR, Glibert PM, Harding LW, Sellner KG (1996) Scales of nutrient-limited phytoplankton productivity in Chesapeake Bay. Estuaries 19:371-385

Marcus NH (1991) Planktonic copepods in a sub-tropical estuary: seasonal patterns in the abundance of adults, copepodites, nauplii, and eggs in the sea bed. Biol Bull 181: 269-274

Mattraw HC, Elder JF (1984) Nutrient and detritus transport in the Apalachicola River, Florida. United States Geological Survey Water Supply Paper, 2196-C, Alexandria, VA

McCracken DD, Dorn WS (1964) Numerical methods and fortran programming. John Wiley and Sons, New York

Meeter DA, Livingston RJ, Woodsum G (1979) Long-term climatological cycles and population changes in a river-dominated estuarine system. In: Livingston RJ (ed) Ecological processes in coastal and marine systems. Plenum Press, New York, p 315-338

Mellor GL, Yamada T (1982) Development of a turbulence closure model for geophysical fluid problems. Rev Geophys 20:851-857

Monbet $Y(1992)$ Control of phytoplankton biomass in estuaries: a comparative analyses of microtidal and macrotidal estuaries. Estuaries 15:563-571

Morel A, Andre JM (1991) Pigment distribution and primary production in the western Mediterranean as derived and modeled from coastal zone color scanner observations. J Geophys Res 96:12685-12698

Mortazavi B, Iverson RL, Huang W, Lewis GF, Caffrey JM (2000) Nitrogen budget of Apalachicola Bay: a bar-built estuary in the northeastern Gulf of Mexico. Mar Ecol Prog Ser 195:1-14

Myers VB, Iverson RL (1977) Aspects of nutrient limitation of the phytoplankton productivity in the Apalachicola Bay system. In: Livingston RJ, Joyce EA (eds) Proceedings of the Conference on the Apalachicola drainage system, 23-24 April 1976. Florida Department of Natural Resources, St Petersburg, FL, p 68-74

Myers VB, Iverson RI (1981) Phosphorus and nitrogen limited phytoplankton productivity in northeastern Gulf of Mexico coastal estuaries. In: Neilson BJ, Cronin LE (eds) Estuaries and nutrients. Humana Press, Clifton, NJ, p 569-582

Nixon SW (1982) Nutrient dynamics, primary production and fisheries yields of lagoons. Oceanol Acta 4(Suppl):357-371 
Nixon SW, Ammerman JW, Atkinson LP, Berounsky VM, Billen G, Boicourt WC, Boynton WR, Church TM, Ditoro DM, Elmgren R, Garber JH, Giblin AE, Jahnke RA, Owens NJP, Pilson MEQ, Seitzinger SP (1996) The fate of nitrogen and phosphorus at the land-sea margin of the North Atlantic Ocean. Biogeochemistry 35:141-180

Pennock JR, Sharp JH (1994) Temporal alteration between light- and nutrient-limitation of phytoplankton production in a coastal plain estuary. Mar Ecol Prog Ser 111: $275-288$

Pennock JR, Boyer JN, Herrera-Silveira JA, Iverson RL, Whitledge TE, Mortazavi B, Comin FA (1999) Nutrient behavior and phytoplankton production in Gulf of Mexico estuaries. In: Bianchi TS, Pennock JR, Twilley RR (eds) Biogeochemistry of Gulf of Mexico estuaries. John Wiley \& Sons, New York, p 109-162

Pugh PR (1970) Liquid scintillation counting of ${ }^{14} \mathrm{C}$-diatom material on filter papers for use in productivity studies. Limnol Oceanogr 15:652-655

Redfield AC (1958) The biological control of chemical factors in the environment. Am Sci 46:205-221

Editorial responsibility: Otto Kinne (Editor), Oldendorf/Luhe, Germany
Ryther JH, Dunstan WM (1971) Nitrogen, phosphorus, and eutrophication in the coastal marine environments. Science 171:1008-1013

Stockner JG, Cliff DD, Shortreed KRS (1979) Phytoplankton ecology of the Strait of Georgia, British Columbia. J Fish Res Board Can 36:657-666

Strickland JD, Parsons TR (1972) A practical handbook of seawater analyses. Bull Fish Res Board Can 167

Twilley RR, Cowan J, Miller-Way T, Montagna P, Mortazavi B (1999) Benthic nutrient fluxes in selected estuaries in the Gulf of Mexico. In: Bianchi TS, Pennock JR, Twilley RR (eds) Biogeochemistry of Gulf of Mexico estuaries. John Wiley \& Sons, New York, p 163-209

Vinogradov A (1953) The elementary chemical composition of marine organisms. Yale University Press, New Haven

Wilber DH (1992) Association between freshwater inflows and oyster productivity in Apalachicola Bay, Florida. Estuar Coast Shelf Sci 35:179-190

Williams P, Robertson JI (1989) A serious inhibition problem from a Niskin sampler during plankton productivity studies. Limnol Oceanogr 34:1300-1305

Submitted: June 3, 1998; Accepted: November 5, 1999 Proofs received from author(s): May 3, 2000 